\title{
25 Research Square \\ Can Environmental Tax Bring Strong Porter Effect? Evidence From Chinese Listed Companies
}

\section{Zhuojun Lei}

Chongqing University

Lingyun Huang ( $\square$ janeleeves@sina.com )

Chongqing University

\section{Yao Cai}

Stockholm School of Economics: Handelshogskolan i Stockholm

\section{Research Article}

Keywords: Porter hypothesis, Environmental tax, Firm performance, Innovation compensation, First-mover advantage

Posted Date: July 12th, 2021

DOI: https://doi.org/10.21203/rs.3.rs-612715/v1

License: @ (1) This work is licensed under a Creative Commons Attribution 4.0 International License. Read Full License

Version of Record: A version of this preprint was published at Environmental Science and Pollution Research on January 11th, 2022. See the published version at https://doi.org/10.1007/s11356-021-17119-9. 


\section{Abstract}

Existing researches verify Porter hypothesis mainly through one of its core establishment paths, innovation compensation, but ignore the other one, first-mover advantage. To further clarify the mechanism of Porter hypothesis, this paper considers both paths and further distinguishes between environmental R\&D and nonenvironmental R\&D. Based on the principle of the smooth transition of "charge to tax" in China, this paper, taking Chinese A-share listed companies that have disclosed environmental R\&D from 2008 to 2017 as sample and predicting environmental tax by pollution charge, analyses the relationship between environmental tax and firm performance and the transmission mechanism between them. Our results show that environmental tax can improve firm performance and this influence remains in long term. After introducing instrument variable (IV) to deal with endogeneity and conducting a series of robustness tests, we find that the relationship between environmental tax and firm performance is robust causality. Furthermore, using mediating effect model to analyse the transmission mechanism, we prove that environmental tax can affect firm performance through innovation compensation and first-mover advantage, which confirms the two core paths of Porter hypothesis. This study reveals the micro mechanism of environmental tax on firm performance, provides evidence from China to support strong Porter hypothesis, and helps guide environmental tax reform and corporate green strategy management.

\section{Introduction}

Negative externality in the exploitation and utilization of environmental resources cannot be solved by market alone. As a form of Pigouvian taxes, pollution charge is an important way to internalize the external cost of a firm. Chinese government promulgated "Interim Measures for the Collection of Pollution Charge" in 1982, which formally established the pollution charge system in China. It has had a profound influence on Chinese environmental governance in more than 30 years. (Guo et al., 2019). In order to further standardize the pollution charges, "Environmental Tax Law of China" was implemented in 2018 to change pollution charges into environmental tax officially. According to the polluter pays principle (PPP), firms are the major object of the environmental tax, which may burden them with more operating cost. So we come up with the following questions naturally: Will environmental tax affect the competitiveness of firms, and can it produce strong Porter effect? If so, what is the path? To answer these two questions is of great significance to evaluate the implementation effect of environmental tax and guide the reform to the next stage.

Although the impact of the levy of environmental tax on macroeconomic development and firms' behavior as micro-players in China is still unknown due to lack of relevant data and short execution time, what is known is that the legislation of environmental tax follows the principle of smooth transition of "charge to tax" that no significant change in the levy object, scope and calculation standard between environmental protection tax and pollution charge (Wang et al., 2019). The biggest change from pollution charge to environmental tax is that the legal status of pollution charge is relatively low, which is easy to form levy and management obstacles (Wang et al., 2003). The inherent legal authority of environmental tax further strengthens the tax rigidity, which will significantly improve the intensity of levy (Xu, 2015; Huang and Li, 2018). Based on the fact that there is no big difference between environmental tax and pollution charge, we can evaluate the implementation effect of Chinese environmental tax through the policy of pollution charge (Lu et al., 2019), and discuss whether 
environmental tax can produce strong Porter effect and how, so as to provide policy reference for the reform of environmental tax.

In order to test Porter hypothesis better, Jaffe and Palmer (1997) divided it into three forms. The first one is weak Porter hypothesis, which implies that strict environmental regulation policy can stimulate innovation in firms, but its influence on innovation that increases firm competitiveness is uncertain. Scholars have basically reached a consensus that the weak Porter hypothesis is tenable. Calel and Dechezleprêtre (2016) found that regulated firms have higher innovation investment than unregulated firms based on European environmental regulation policy research. Empirical studies by Manderson and Kneller (2012), Nesta et al. (2014), Song et al. (2019) and Shang et al. (2021) also found that environmental regulation and innovation are positively correlated; The second is the narrow Porter hypothesis, which indicates that flexible regulatory policies incentivize firms greater to innovate than stiff ones. López-Gamero et al. (2010) found that flexible environmental regulation is conducive to encourage firms to develop new processes and products while stiff regulatory policies are not. Jaffe et al. (2002), Brouhle et al. (2013), Ambec et al. (2013) and Sun et al. (2021) also prove that compared with direct regulation based on command and control such as environmental standards and emission limits, market-based and flexible regulation greater motivate firms to innovate; The third is the strong Porter hypothesis, which means that innovation in firms provoked by stronger environmental regulation can completely offset any additional costs from environment protection and improve firms' competitiveness. The conclusions of existing researches on strong Porter hypothesis are controversial, and scholars often conduct research from the perspective of productivity. Dension (2010) found that the reason for the productivity of the United States decreased by $16 \%$ during $1972-1975$ is the intensified environmental regulation. Cagatay and Mihci (2006) and Hering and Poncet (2014) also get a similar conclusion that environmental regulation have adverse effect on competitiveness. However, Berman and Bui (2001) found that the productivity growth of the petroleum smelting industry in Los Angeles, where strict air quality control has been implemented, is much higher than that in other parts of the United States. Other literature such as, Hamamoto (2006), Peuckert (2014), Wang et al. (2019), found evidence that environmental regulation improves productivity as well.

From the literature above, we can see that the major controversy existing in three forms of Porter hypothesis is the strong Porter hypothesis. We infer that there are four important reasons for the inconsistency. Firstly, Porter and Van der linde (1995) believe that strict and properly designed environmental regulation can stimulate innovation and partially or completely offset the adverse effect of compliance cost. Therefore, the prerequisite in the establishment of the strong Porter hypothesis is strict and properly designed environmental regulation. Although what is "strict and properly designed" environmental regulation is still inconclusive, studies have confirmed that there is an inflexibility in command-control environmental regulation, and inflexible regulation even inhibits the environmental innovation behavior in firms (Montero, 2002; Reequate and Unold, 2003). The comprehensive environmental regulation indicators used in literature often include inflexible environmental regulation, which may make the results inaccurate for they do not comply the prerequisite of the strong Porter hypothesis. Secondly, environmental regulation indicators are often endogenous in economic research (Copeland and Taylor, 2004): Environmental regulation variables and dependent variables are reciprocal causation, or environmental regulation variables correlated with omitted variables and other unobservable factors leads to endogenous problems, which will affect the accuracy of the conclusion greatly. Thirdly, the existing literature does not make a clear distinction between environmental innovation and non-environmental 
innovation. Researchers often consider the overall innovation in firms, but environmental regulation promotes green-biased innovation the most (Requate and Unold, 2003; Acemoglu, 2012), and the effects of the two types of innovation on firms competitiveness are obviously different, misleading the results. Fourth, most of the researches measure the firm competitiveness by their total factor productivity (TFP). In fact, the firm competitiveness is also affected by many factors in addition to TFP, including demand factors, factor endowments and corporate image, etc. For example, the environmental protection behavior of a firm may also enhance competitiveness through providing environment-friendly products and establishing a green corporate social image. Kammerer (2008) found that some consumers are more willing to pay for green products with high prices when the products reduce pollution and have added value.

We attempt to alleviate the four problems mentioned above. Taking Chinese A-share listed companies that disclosed environmental R\&D from 2008 to 2017 as samples, we focus on the environmental tax which is the most typical market-oriented environmental regulation in China[1]. We measure firm competitiveness by firm performance to test whether environmental tax can produce strong Porter effect. Furthermore, instrumental variable is introduced to reduce the adverse effect of endogeneity, and a series of robustness tests are conducted to prove that there is a stable causal relationship between environmental tax and firm performance. In the end, this paper establishes a mediating effect model to analyse the mechanism from environmental tax to firm competitiveness according to two paths of Porter hypothesis - innovation compensation and firstmover advantage. Figure 1 shows the empirical research framework of this paper.

This paper may have the following marginal contributions. First of all, the existing studies do not explain the mechanism of environmental regulation affecting firm competitiveness clearly. On the one hand, although there are relevant literature on mechanism of innovation compensation, they do not further distinguish between environmental R\&D and non-environmental R\&D that whose impacts are obviously different. This paper separates environmental innovation from overall innovation by collecting the corporate environmental R\&D data in CSR reports, focusing on whether environmental innovation can bring innovation compensation effect. On the other hand, previous researches mainly discuss about innovation compensation but ignore the effect of first-mover advantage although Porter hypothesis contains these two core paths. On the contrary, this paper analyses both the effects of innovation compensation and first-mover advantage, providing micro evidence from China to validate strong Porter hypothesis and its mechanism. Secondly, this paper fully considers the endogenous problem resulting from reciprocal causation and omitted variables. We prove that there is a robust causal relationship between environmental tax and firm performance by introducing instrumental variables and conducting a series of robustness tests, which provides causal identification evidence for the strong Porter hypothesis. Thirdly, although a handful of literature compare different types of environmental regulation rather than only use comprehensive environmental regulation as independent variable, it is difficult to analyse the causality and mechanism of specific environmental regulation tools under this approach. For more in-depth analysis, this paper only takes the most typical market-based environmental regulation in China, environmental tax, into consideration and discusses corresponding causality relationship and influence mechanism.

This study proceeds as follows. Section 2 contains Policy background and characteristic facts. Section 3 provides the methodology and describes the data. Section 4 discusses empirical procedures and major findings. Section 5 consists of research conclusions and policy recommendations. 
[1] Market based environmental regulation mainly includes environmental tax, emissions trading, subsidies and deposit return. Emission trading in China is only carried out in some areas, and the trading volume is still small while the subsidy and deposit return are lack of corresponding data.

\section{Policy Background And Characteristic Facts}

\section{From pollution charge to environmental tax}

Pollution charge made its debut out of the polluter pays principle (PPP) proposed by the Environment Committee of the Organization for Economic Cooperation and Development (OECD) in 1972. The "Environmental Protection Law of China for Trial Implementation" proposed in 1979 marked the establishment of pollution charge policy in some pilot areas in China. China issued the "Interim Measures for the Collection of Pollution Charge" in 1982, indicating that the pollution charge policy was formally established and widely implemented throughout the country. China promulgated "Regulation on the Administration of Collection and Use of Pollutant Discharge Fees" in 2003, which improved the pollution charge system greatly. The original charge for single factor of pollution exceeding the standard was replaced by the total multi-factor charge based on the type and quantity of pollutants.

Pollution charge policy has played a significant role for nearly 40 years in China, but environmental problems are still common in China (Xu and Xie, 2016). The limitations of the pollution charge are exposed gradually, mainly due to the lack of rigidity in law enforcement and excessive intervention by local governments (Lu et al., 2019). In order to improve these deficiencies, the "Environmental Tax Law of China" was implemented in 2018, presenting that the pollution charge is transformed into environmental tax officially. The legislation of environmental tax is based on the principle of smooth transition of "charge to tax". Therefore, the object, scope and calculation standard of environmental tax are basically the same as that of pollution charge. The biggest difference between the two policies exists in normative where environmental tax is based on basic law and the levy subject is tax department while pollution charge based on administrative regulations and collected by local environmental department is not standardized in the implementation. Some studies have clearly pointed out that local governments in China will slack the collection of pollution charge for large taxpayer for the sake of local GDP (Xi et al., 2018; Zhang et al., 2021). In a word, there are a lot of similarities between pollution charge and environmental tax. However, it is an indisputable fact that the intensity of levy will increase after the "charge to tax" reform.

\section{Characteristic facts}

According to the polluter pays principle (PPP), firms are the basic units that pay for pollution. Figure 2 shows the total amount of pollution charge and the total number of firms paid for pollution in China from 1995 to 2015. The amount of pollution has overall maintained a rising trend. It is worth noting that the amount of pollution charge has increased sharply after 2003. One reason is that the new regulation issued in 2003 requires double charge have to be paid for the pollution amount exceeding emission standard. The number of firms paying pollution charges began to decline significantly after 2003. There are two possible reasons: First, the introduction of new regulations in 2003 has greatly increased the pollution costs of firms. Firms have to adopt cleaner and more efficient technologies to reduce pollution emission out of maximizing their own interests, and some firms refrain from paying charge due to their effective green transformation. Second, firms 
with weak innovation ability and low productivity will face high pollution costs in the already competitive market and could be eliminated from the competition and exit the market eventually. A possible reason for the slowing growth rate of pollution charge after 2008 is that local governments have to loosen the collection of pollution charge to secure economic growth under the impact of economic crisis. Combining observations on amount of pollution charge and the number of paying firms, we find that the number of paying firms has been declining since 2003, while the general trend in the amount of pollution charge is still rising, which indirectly indicates that the actual intensity of levy is increasing. Figure 3 shows the details of pollution charge in several years. It can be found that pollution charge mainly levies on waste gas and water, while the charge for industrial residue and noise only accounts for a small proportion. Therefore, two emission indicators, waste gas and polluted water, are used to measure the intensity of environmental tax in our paper.

\section{Methodology}

\section{Data source and processing}

The study sample consists of Chinese A-shares listed companies in the period of 2008-2017. We choose this time interval out of the following two reasons: First, China Securities Regulatory Commission has recommended listed companies to issue corporate social responsibility (CSR) reports since 2008, so corporate environmental R\&D data can be obtained from 2008. Second, 2017 is the last year for the collection of pollution charge and from 2018 environmental tax is levied, but no corresponding data is available at present. The raw data is processed as following rules: (1) Data with missing values in variables are eliminated. (2) Samples of special treatment (ST, *ST, SST) listed companies are excluded. (3) Samples of financial firms are excluded. This leads to a final sample of 223 firms with an unbalanced panel of 901 firm-year observations. In order to avoid interference caused by extreme outliers, all continuous variables are winsorized on the $1 \%$ and $99 \%$ quantile. The data in this paper mainly come from China energy Statistical Yearbook (2008-2017), China Environmental Statistical Yearbook (1995-2016), China Statistical Yearbook (2008-2016), corporate social responsibility (CSR) report and China Stock Market and Accounting Research (CSMAR) database. The descriptive statistics for all the variables are provided in Table 1.

\section{Variable description}

\section{Dependent variable}

Scholars mainly use return on assets (ROA) and TobinQ as proxy variables of firm performance (Morgan et al., 2002). The calculation of TobinQ value involves the internal financial data and external market data. However, the effectiveness of the Chinese capital market has been questioned by some scholars due to its incomplete construction and irrational investor (Xu et al., 2006). Therefore, we use return on assets (ROA), return on equity (ROE) and return on sales (ROS) as proxy variables of firm performance in baseline regression and TobinQ in robustness check.

\section{Independent variables}

This paper uses pollution charge data to predict and analyse environmental tax, as there is no available data on Chinese environmental tax by now. We argue that this method holds because similarities do exist between 
these two caused by smooth transition of "charge to tax" reform mentioned above. Lu et al. (2019) also point out that the types of pollution charge include polluted water, waste gas, industrial residue and noise, which has no substantial change after the "charge to tax" reform. It can be seen from Figure 3 that the charge for industrial residue and noise only account for a small proportion, and there are also many missing values in the data of industrial residue and noise emission. Therefore, referring to Shen et al. (2017), we select $\mathrm{SO}_{2}$ and COD in waste gas and water as pollution indicators, and calculate the common pollution factor by factor analysis method and use the ratio of pollution charge and the common pollution factor as proxy variables of environmental tax.

\section{Mediating variable}

China Securities Regulatory Commission issued the guidelines for environmental information disclosure of listed companies in 2008 to encourage listed companies to disclose environmental information in corporate social responsibility (CSR) report. Some listed companies have disclosed environmental R\&D since then, which provides data support for this study. These data are mainly disclosed in the environmental protection and sustainable development parts of the CSR report. We manually collected the data from 2008 to 2017. In line with Wang et al. (2017), we use the natural logarithm for the initial environmental R\&D data to avoid the influence of heteroscedasticity. The market share is measured by the ratio of the revenue of firms to the total revenue of their belonged industry according to the industry classification standard of China Securities Regulatory Commission (2012).

\section{Control variables}

Refering to Rammer et al. (2017), this research select the control variables from three aspects of corporation characteristics, financial position and firm governance. The specific control variables are selected as following: (1) Firm size (Size), measured by natural logarithm of the total assets of the firms. (2) Financial leverage (Lev), measured by the ratio of total liabilities to total assets. (3) Management expenses (Cost), measured by the ratio of management expenses to total revenue. (4) Equity concentration (Top1), measured by the shareholding ratio of the largest shareholder of the firm. (5) Growth of firm (Growth), measured by increase rate of main business revenue. We also control regional variables to reduce the adverse effects of omitted variables: (6) Regional economic development level (GDP), measured by regional real GDP growth rate. (7) Regional market environment (Market), measured by regional Marketization Index.

\section{Table 1 Summary statistics of the variables.}




\begin{tabular}{lllllll} 
Variable & Obs. & Mean & P50 & Std. Dev. & Min. & Max. \\
\hline ROA & 901 & 0.040 & 0.031 & 0.057 & -0.341 & 0.464 \\
\hline ROE & 901 & 0.073 & 0.073 & 0.153 & -1.806 & 1.036 \\
\hline ROS & 901 & 0.063 & 0.047 & 0.129 & -1.200 & 0.534 \\
\hline Tax & 901 & 0.074 & 0.051 & 0.086 & 0.007 & 0.805 \\
\hline ERD & 901 & 17.392 & 17.409 & 1.960 & 10.859 & 22.965 \\
\hline MS & 901 & 0.047 & 0.042 & 0.028 & 0.002 & 0.161 \\
\hline Size & 901 & 23.492 & 23.315 & 1.414 & 19.865 & 28.098 \\
\hline Lev & 901 & 0.526 & 0.538 & 0.180 & 0.048 & 0.982 \\
\hline Cost & 901 & 0.070 & 0.061 & 0.051 & 0.006 & 0.612 \\
\hline Top1 & 901 & 42.064 & 41.620 & 16.091 & 6.470 & 88.550 \\
\hline Growth & 901 & 0.150 & 0.100 & 0.367 & -0.539 & 4.650 \\
\hline GDP & 901 & 0.097 & 0.090 & 0.026 & -0.025 & 0.174 \\
\hline Market & 901 & 7.328 & 7.410 & 1.820 & 2.220 & 10.650
\end{tabular}

\section{Model}

To investigate the impact of environmental tax on firm performance, we run the following baseline regression:

Performance $, t,_{i}=\alpha_{0}+\alpha_{1}$ Tax $_{i, t}+\alpha_{2}$ Control $_{i, t}+\mu_{i}+\lambda_{t}+\varepsilon_{i, t}$

where Performance ${ }_{i, t}$ represents firm performance including ROA, ROE and ROS and Tax $\mathrm{T}_{\mathrm{i}, \mathrm{t}}$ represents environmental tax[1]. $\mathrm{X}_{\mathrm{i}, \mathrm{t}}$ contains following control variables: Size, Lev, Cost, Top1, Growth, GDP and Market. The results of $F$ test and Hausman test lead us to use Two-Way fixed effect (FE) models to estimate. $\mu_{i}$ and $\lambda_{t}$ control the firm fixed effect and annual fixed effect respectively, and $\varepsilon_{i, t}$ is disturbance term.Considering that the disturbance term may have heteroscedasticity, we use Wald test to test it under the fixed effect, and the results show that heteroscedasticity exists, so the standard errors are clustered on the firm level for robust adjustment.

[1] In fact, there may be a reciprocal causation between environmental tax and firm performance. Therefore, we have added the environmental tax variable lagged one period to reduce the negative impact of reciprocal causation. But this approach can not completely deal with endogenous issues, and we will further use IV method to address endogenous issues.

\section{Empirical Results}

\section{Baseline regression}


The baseline regression results are represented in Table 2. From the results of columns 1-3 in Table 2, the regression coefficients of Tax are significantly positive, indicating that there is a positive correlation between environmental tax and firm performance. In order to test the long-term effect of environmental tax and reduce the impact of reciprocal causation, we also test the environmental tax lagged one period in the baseline regression. From the results of columns 4-6 in table 2, the regression coefficient of Tax is still significantly positive, which indicates that the positive promotion effect of environmental tax on firm performance can be long-term. However, it is worth noticing that this paper only takes the firms that are going concern into this regression because those low-tech firms that are unable to create effective green innovation could be gradually eliminated by the market due to the increase of operating costs. So the conclusion may only hold true for the firms that survive in the market.

\section{Table 2 The results of baseline regression}




\begin{tabular}{|c|c|c|c|c|c|c|}
\hline & (1) & $(2)$ & (3) & (4) & (5) & (6) \\
\hline & ROA & ROE & ROS & ROA & ROE & ROS \\
\hline \multirow[t]{2}{*}{ Tax } & $0.1045^{\star \star \star}$ & $0.2256^{\star \star}$ & $0.2675^{\star \star \star}$ & & & \\
\hline & $(0.0319)$ & $(0.0884)$ & $(0.0746)$ & & & \\
\hline \multirow[t]{2}{*}{ LTax } & & & & $0.1049 * \star \star$ & $0.2675^{\star \star \star}$ & 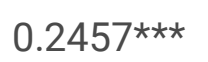 \\
\hline & & & & $(0.0289)$ & $(0.0822)$ & $(0.0784)$ \\
\hline \multirow[t]{2}{*}{ Size } & $-0.0116^{\star \star}$ & -0.0030 & -0.0102 & $-0.0157^{\star \star \star}$ & -0.0174 & -0.0127 \\
\hline & $(0.0059)$ & $(0.0163)$ & $(0.0138)$ & $(0.0056)$ & $(0.0159)$ & $(0.0149)$ \\
\hline \multirow[t]{2}{*}{ Lev } & $0.0083^{\star \star}$ & 0.0074 & $0.0303^{\star \star \star}$ & $0.0108^{\star \star \star}$ & 0.0114 & $0.0296^{\star \star \star}$ \\
\hline & $(0.0036)$ & $(0.0100)$ & $(0.0085)$ & $(0.0036)$ & $(0.0103)$ & $(0.0088)$ \\
\hline \multirow[t]{2}{*}{ Cost } & $-0.4141 * \star \star$ & $-1.4424^{\star \star \star}$ & $-1.1393^{\star \star \star}$ & $-0.4359 * \star \star$ & $-1.5142^{\star \star *}$ & $-1.1172^{\star \star \star}$ \\
\hline & $(0.0782)$ & $(0.2165)$ & $(0.1828)$ & $(0.0806)$ & $(0.2293)$ & (0.1955) \\
\hline \multirow[t]{2}{*}{ Top1 } & -0.0003 & -0.0012 & 0.0000 & $-0.0005^{\star}$ & $-0.0016^{\star \star}$ & -0.0000 \\
\hline & $(0.0003)$ & $(0.0008)$ & $(0.0006)$ & $(0.0003)$ & $(0.0008)$ & $(0.0007)$ \\
\hline \multirow[t]{2}{*}{ Growth } & $0.0207 * \star \star$ & 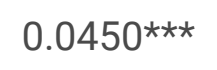 & $0.0280 * \star \star$ & $0.0256^{\star \star \star}$ & $0.0588 * \star \star$ & $0.0267^{\star *}$ \\
\hline & $(0.0042)$ & $(0.0116)$ & $(0.0098)$ & $(0.0042)$ & $(0.0120)$ & $(0.0107)$ \\
\hline \multirow[t]{2}{*}{ GDP } & 0.1105 & 0.1295 & 0.3008 & 0.0950 & 0.1622 & 0.3552 \\
\hline & $(0.1156)$ & $(0.3201)$ & $(0.2703)$ & $(0.0865)$ & $(0.2461)$ & $(0.2959)$ \\
\hline \multirow[t]{2}{*}{ Market } & $-0.0074^{\star}$ & -0.0091 & 0.0019 & $-0.0093^{\star \star \star}$ & $-0.0180 * \star$ & 0.0019 \\
\hline & $(0.0041)$ & $(0.0114)$ & $(0.0096)$ & $(0.0030)$ & $(0.0085)$ & $(0.0101)$ \\
\hline Firm FE & Yes & Yes & Yes & Yes & Yes & Yes \\
\hline Year FE & Yes & Yes & Yes & Yes & Yes & Yes \\
\hline \multirow[t]{2}{*}{ Constant } & $0.2234^{\star \star}$ & 0.2233 & -0.3184 & $0.2787^{\star \star \star}$ & 0.4993 & -0.2255 \\
\hline & $(0.1122)$ & $(0.3108)$ & $(0.2624)$ & $(0.1068)$ & $(0.3036)$ & $(0.2970)$ \\
\hline $\mathrm{N}$ & 901 & 901 & 901 & 839 & 839 & 839 \\
\hline Adj $R^{2}$ & 0.3095 & 0.2629 & 0.2338 & 0.2533 & 0.2059 & 0.2217 \\
\hline
\end{tabular}

Note: $(1){ }^{\star \star \star} p<0.01,{ }^{* \star} p<0.05,{ }^{*} p<0.1$. (2) Figures in parentheses are robust standard errors cluster on firm level.

\section{Endogenous problems}

Many literatures point out that there exist endogenous issues among environmental tax (Copeland and Taylor, 2004; Rubashkina et al., 2015). Although this paper has tested environmental tax variables lagged one period, 
the endogeneity may still exist because of omitted variables. In order to overcome it, this paper further uses IV2SLS method to conduct empirical tests for environmental tax and firm performance. The selection of IV should satisfies two conditions. One is that IV should be highly correlated with explanatory variables. The other is that the IV is not related to the disturbance term. We select standard coal of regional energy consumption as IV of environmental tax, and the data come from China energy statistics yearbook (2008-2017). There are two reasons why standard coal of regional energy consumption is a feasible instrumental variable. Firstly, this IV meets the first condition, that is, it is highly related to environmental tax, because each region formulates environmental tax policy according to its own energy dependence correspondingly. Secondly, this IV meets the second condition that the regional standard coal of energy consumption will not affect firm performance directly.

Table 3 shows the regression results of IV-2SLS. Column 1 of Table 3 reports the first stage regression results, showing that there is a significant negative correlation between standard coal of energy consumption and environmental tax, which is in line with our expectation that the more a region relies on high energy consumption industries, the lower the intensity of emission levy will be set. The regression results in the first stage prove that the IV is highly correlated with independent variables again. The Kleibergen-Paap rk LM statistics which are employed to examine whether the selected IV and the endogenous variables are relevant, are all significant at the level of 0.01 , indicating that the under-identification hypothesis is rejected. In addition, the Kleibergen-Paap rk Wald F statistics are exceed the critical value of the Stock-Yogo test at $10 \%$ level, which indicates that the weak instrument variable problem can be eliminated. The regression coefficients of Tax in column 2-4 of Table 3 are significantly positive, showing that the relationship between environmental tax and firm performance is causality after overcoming the endogenous problem.

\section{Table 3 The results of IV-2SLS}


First Stage Second Stage

\begin{tabular}{|c|c|c|c|c|}
\hline & (1) & (2) & (3) & (4) \\
\hline & Tax & ROA & ROE & ROS \\
\hline \multirow[t]{2}{*}{ Energy } & $-0.0012^{\star \star \star}$ & & & \\
\hline & $(0.0002)$ & & & \\
\hline \multirow[t]{2}{*}{ Tax } & & 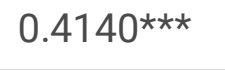 & $1.0271^{\star \star \star}$ & $0.6540 * \star \star$ \\
\hline & & $(0.1124)$ & $(0.2936)$ & $(0.2224)$ \\
\hline \multirow[t]{2}{*}{ Size } & $-0.0167 \star \star$ & -0.0082 & 0.0033 & -0.0038 \\
\hline & $(0.0083)$ & $(0.0086)$ & $(0.0284)$ & $(0.0191)$ \\
\hline \multirow[t]{2}{*}{ Lev } & $0.0101^{*}$ & 0.0062 & 0.0007 & $0.0256^{\star \star}$ \\
\hline & $(0.0052)$ & $(0.0047)$ & $(0.0134)$ & $(0.0117)$ \\
\hline \multirow[t]{2}{*}{ Cost } & $-0.3177^{*}$ & $-0.3579 * \star \star$ & $-1.3182^{\star * *}$ & $-1.1463^{\star \star}$ \\
\hline & $(0.1701)$ & $(0.1085)$ & $(0.4236)$ & $(0.4506)$ \\
\hline \multirow[t]{2}{*}{ Top1 } & -0.0003 & -0.0003 & $-0.0014^{*}$ & -0.0000 \\
\hline & $(0.0003)$ & $(0.0004)$ & $(0.0008)$ & $(0.0007)$ \\
\hline \multirow[t]{2}{*}{ Growth } & 0.0066 & $0.0229 * \star \star$ & $0.0511^{* \star \star}$ & $0.0303^{* \star}$ \\
\hline & $(0.0054)$ & $(0.0063)$ & $(0.0158)$ & $(0.0121)$ \\
\hline \multirow[t]{2}{*}{ GDP } & 0.3697 & -0.0275 & -0.1202 & 0.1038 \\
\hline & $(0.2706)$ & $(0.1315)$ & $(0.3450)$ & $(0.3058)$ \\
\hline \multirow[t]{2}{*}{ Market } & $0.0127 * \star$ & $-0.0111^{\star \star \star}$ & $-0.0240 * \star$ & $-0.0135^{\star}$ \\
\hline & $(0.0059)$ & $(0.0041)$ & $(0.0109)$ & $(0.0077)$ \\
\hline Firm FE & Yes & Yes & Yes & Yes \\
\hline Year FE & Yes & Yes & Yes & Yes \\
\hline \multirow[t]{2}{*}{ Kleibergen-Paap rk LM statistic } & & 38.596 & 38.596 & 38.596 \\
\hline & & {$[0.00]$} & {$[0.00]$} & {$[0.00]$} \\
\hline \multirow[t]{2}{*}{ Kleibergen-Paap rk Wald F statistic } & & 33.003 & 33.003 & 33.003 \\
\hline & & $\{16.38\}$ & $\{16.38\}$ & $\{16.38\}$ \\
\hline $\mathrm{N}$ & $849[1]$ & 849 & 849 & 849 \\
\hline
\end{tabular}

Note: (1) *** $p<0.01$, $* \star 0<0.05, * p<0.1$. (2) Figures in parentheses are robust standard errors cluster on firm level. (3) Figures in [ are the p-values of Kleibergen-Paap rk LM test statistics, and figures in $\}$ are the critical values at the $10 \%$ level of Stock-Yogo test. 


\section{Robustness check}

In order to further check the reliability of the conclusion, we carry out robustness check from three aspects. The first is the replacement of dependent variable. In order to consider the performance of firms in the capital market, we use TobinQ value as the dependent variable to do the regression again, and the results are shown in column 1 of Table 4. The second one is the replacement of the independent variable. We use the ratio of pollution charge and industrial value added (IVA) as Tax 2 for the proxy variable of environmental tax, and the results are shown in column 2-4 of Table 4. The third one is the replacement of regression model. Considering that missing variables may exist in the industry and region level, we control the fixed effect of industry and region rather than of firm in new regression model, and the results are shown in column 5-7 of Table 4. In a word, we can see that the regression results in Table 4 are consistent with the main conclusions above, further proving that the conclusions of this paper are robust.

\section{Table 4 The results of robustness check}


(1)

(2)

(3)

(4)

(5)

(6)

(7)

\begin{tabular}{|c|c|c|c|c|c|c|c|}
\hline & TobinQ & ROA & ROE & ROS & ROA & ROE & ROS \\
\hline \multirow[t]{2}{*}{ Tax } & $0.7375^{\star \star \star}$ & & & & $0.0996 * \star$ & $0.2222^{\star}$ & $0.1908^{\star *}$ \\
\hline & $(0.2751)$ & & & & $(0.0477)$ & $(0.1184)$ & $(0.0896)$ \\
\hline \multirow[t]{2}{*}{ Tax2 } & & $0.0015^{\star \star}$ & $0.0027 *$ & 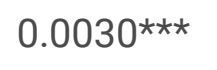 & & & \\
\hline & & $(0.0007)$ & $(0.0016)$ & $(0.0010)$ & & & \\
\hline \multirow[t]{2}{*}{ Size } & $-0.4347^{* \star \star}$ & -0.0114 & -0.0025 & -0.0095 & $-0.0179 * \star *$ & $-0.0274 * * *$ & $-0.0306 * \star \star$ \\
\hline & $(0.0889)$ & $(0.0072)$ & $(0.0231)$ & $(0.0138)$ & $(0.0030)$ & $(0.0070)$ & $(0.0072)$ \\
\hline \multirow[t]{2}{*}{ Lev } & -0.0008 & $0.0087^{\star *}$ & 0.0084 & $0.0316^{\star \star \star}$ & $0.0194^{\star \star \star}$ & $0.0354^{\star \star \star}$ & $0.0414^{\star \star \star}$ \\
\hline & $(0.0427)$ & $(0.0043)$ & $(0.0119)$ & $(0.0085)$ & $(0.0029)$ & $(0.0073)$ & $(0.0065)$ \\
\hline \multirow[t]{2}{*}{ Cost } & 0.7933 & $-0.4275^{\star \star \star}$ & $-1.4786 * \star \star$ & $-1.1851^{\star \star \star}$ & 0.0603 & 0.0200 & $0.3935^{\star \star \star}$ \\
\hline & $(1.5033)$ & $(0.1290)$ & $(0.5274)$ & $(0.1823)$ & $(0.0376)$ & $(0.1200)$ & $(0.0929)$ \\
\hline \multirow[t]{2}{*}{ Top1 } & -0.0062 & -0.0003 & -0.0013 & -0.0001 & 0.0001 & -0.0000 & 0.0002 \\
\hline & $(0.0041)$ & $(0.0004)$ & $(0.0010)$ & $(0.0006)$ & $(0.0001)$ & $(0.0003)$ & $(0.0003)$ \\
\hline \multirow[t]{2}{*}{ Growth } & 0.0759 & $0.0208^{\star \star \star}$ & 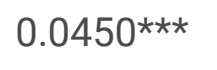 & 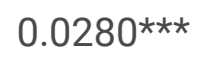 & $0.0263^{\star * *}$ & 0.0632 *** & $0.0486^{\star \star \star}$ \\
\hline & $(0.0538)$ & $(0.0065)$ & $(0.0152)$ & $(0.0098)$ & $(0.0081)$ & $(0.0184)$ & $(0.0110)$ \\
\hline \multirow[t]{2}{*}{ GDP } & 2.6625 & 0.0702 & 0.0602 & 0.2257 & 0.1128 & 0.3741 & 0.5199 \\
\hline & $(1.6524)$ & $(0.1380)$ & $(0.3498)$ & $(0.2730)$ & $(0.1451)$ & $(0.3733)$ & $(0.3335)$ \\
\hline \multirow[t]{2}{*}{ Market } & 0.0607 & -0.0077 & -0.0090 & 0.0024 & -0.0048 & -0.0018 & 0.0025 \\
\hline & $(0.0459)$ & $(0.0065)$ & $(0.0139)$ & $(0.0096)$ & $(0.0064)$ & $(0.0135)$ & $(0.0117)$ \\
\hline \multirow[t]{2}{*}{ Constant } & 10.6036 *** & 0.2189 & 0.2087 & -0.3377 & 0.0836 & -0.0104 & $-0.2576^{\star}$ \\
\hline & (1.8879) & $(0.1575)$ & $(0.4277)$ & $(0.2631)$ & $(0.0683)$ & $(0.1562)$ & $(0.1562)$ \\
\hline Firm FE & Yes & Yes & Yes & Yes & No & No & No \\
\hline Year FE & Yes & Yes & Yes & Yes & Yes & Yes & Yes \\
\hline $\begin{array}{l}\text { Region } \\
\text { FE }\end{array}$ & No & No & No & No & Yes & Yes & Yes \\
\hline $\begin{array}{l}\text { Industry } \\
\text { FE }\end{array}$ & No & No & No & No & Yes & Yes & Yes \\
\hline$N$ & 901 & 901 & 901 & 901 & 901 & 901 & 901 \\
\hline Adj $R^{2}$ & 0.2602 & 0.3109 & 0.2613 & 0.2288 & 0.2856 & 0.2335 & 0.2280 \\
\hline
\end{tabular}

Note: (1) ${ }^{\star \star \star} p<0.01, * \star p<0.05, * p<0.1$. (2) Figures in parentheses are robust standard errors cluster on firm level. 


\section{Path analysis}

We have already known a robust causal relationship between environmental tax and firm performance after applying the IV-2SLS method and a series of robustness tests. Then, another important question is that what is the path of environmental tax affecting firm performance?

Based on Porter hypothesis, we speculate that firms offset the adverse effect of compliance cost and further improve their performance through the effect of innovation compensation and first-mover advantage. Brandt et al. (2012) and Tombe and Winter (2015) have confirmed our other speculation that environmental tax plays a role in eliminating backward production capacity and optimizing allocation of resources. Therefore, the environmental R\&D and market share of firms may play a partial mediating role in the process of environmental tax affecting firm performance. More specifically, corporate environmental R\&D can bring innovation compensation and improve firm performance by improving production technology, optimizing production process, increasing energy efficiency and utilizing recyclable wastes; Firms who pay more attention to consumers' green preference can provide environment-friendly products and further occupy new markets, establishing a good corporate image, improving firm performance through first-mover advantage. Figure 4 shows the mechanism of Porter hypothesis.

According to Baron and Kenny (1986), the specific steps to test mediating effect are as follows: (1) Establish the regression between independent variable (Tax) and dependent variable (Performance), and test whether the regression coefficient of the independent variable (Tax) is significant. If not, there is no stable relationship between the two, and the mediating effect is impossible. If it is significant, we proceed to the second step. (2) Establish the regression of independent variable (Tax) to mediating variables (ERD and MS) in turn. If the coefficients of independent variable (Tax) are not significant, there is no mediating effect. If they are significant, go to the third step. (3) Establish the regression of independent variable (Tax) and mediating variables (ERD and MS) to dependent variable (Performance). If the coefficients of independent variable (Tax) and mediating variables (ERD and MS) are all significant, there is partial mediating effect. If the coefficients of the mediating variables (ERD and MS) are significant while the coefficient of the independent variable (Tax) is not significant, there is a complete mediating effect. (4) If at least one of the mediating variable coefficients in the regressions above is not significant, Sobel (1982) test is required.

Referring to Baron and Kenny (1986), this paper run the following mediating effect regression model:

Performance $_{i, t}=\beta_{0}+\beta_{1}$ Tax $_{i, t}+\beta_{2}$ Control $_{i t}+\mu_{i}+\lambda_{t}+\varepsilon_{i, t}$

$E R D_{i, t}=\gamma_{0}+\gamma_{1} \operatorname{Tax}_{i, t}+\gamma_{2}$ Control $_{i, t}+\mu_{i}+\lambda_{t}+\varepsilon_{i, t}$

$M S_{i, t}=\varphi_{0}+\varphi_{1} \operatorname{Tax}_{i, t}+\varphi_{2}$ Control $_{i, t}+\mu_{i}+\lambda_{t}+\varepsilon_{i, t}$

Performance $_{i, t}=\delta_{0}+\delta_{1} \operatorname{Tax}_{i, t}+\delta_{2} E_{R D_{i, t}}+\delta_{3} M S_{i, t}+\delta_{4}$ Control $_{i, t}+\mu_{i}+\lambda_{t}+\varepsilon_{i, t}$

where $E R D_{i, t}$ represents corporate environmental $R \& D$ and $M S_{i, t}$ represents firm market share. The remaining variables are the same as the baseline model. 
We have completed the first step in mediating effect test above (see the regression results of column 1-3 in Table 2), so here we start from the second step. There is a significant positive correlation (column 1 in Table 5) between environmental tax and firm environmental R\&D, meaning that environmental tax can stimulate firms to increase investment in environmental innovation, which also proves the weak Porter hypothesis. The regression results of the column 2 in Table 5 show that the environmental tax increases the market share of firm. The reason for this result may be that firms can give full play to the first-mover advantage to expand market or seize the new market through providing environment-friendly products, meeting the green preference of some consumers and breaking the original market boundaries. Then we include environmental tax, environmental R\&D and market share into the model at the same time and the results of column 3-5 in Table 5 show that the regression coefficients of the three variables are significantly positive, which indicates that environmental R\&D and market share play the partial mediating effect. In summary, the conclusions prove that environmental tax can improve firm performance and produce strong Porter effect through two paths, innovation compensation and first-mover advantage.

\section{Table 5 The results of mediating effect model}


(1)

(2)

(3)

(4)

(5)

\begin{tabular}{|c|c|c|c|c|c|}
\hline & ERD & MS & ROA & ROE & ROS \\
\hline \multirow[t]{2}{*}{ Tax } & $2.1113^{\star \star \star}$ & $0.0479 * * *$ & $0.0972^{\star \star \star}$ & $0.2359 * \star \star$ & $0.2375^{\star \star \star}$ \\
\hline & $(0.6839)$ & $(0.0073)$ & $(0.0290)$ & $(0.0810)$ & $(0.0684)$ \\
\hline \multirow[t]{2}{*}{ ERD } & & & $0.0034^{\star \star}$ & $0.0082^{\star}$ & $0.0066^{*}$ \\
\hline & & & $(0.0016)$ & $(0.0044)$ & $(0.0037)$ \\
\hline \multirow[t]{2}{*}{ MS } & & & $0.8468^{\star \star \star}$ & $1.8051^{\star \star \star}$ & $1.1862^{\star \star \star}$ \\
\hline & & & $(0.1477)$ & $(0.4128)$ & $(0.3485)$ \\
\hline \multirow[t]{2}{*}{ Size } & $0.6566^{\star * *}$ & $-0.0096 * * *$ & $-0.0112^{\star \star}$ & -0.0076 & -0.0082 \\
\hline & $(0.1280)$ & $(0.0014)$ & $(0.0056)$ & $(0.0155)$ & $(0.0131)$ \\
\hline \multirow[t]{2}{*}{ Lev } & 0.0216 & 0.0002 & $0.0090 * \star$ & 0.0080 & $0.0292^{\star \star \star}$ \\
\hline & $(0.0862)$ & $(0.0009)$ & $(0.0035)$ & $(0.0099)$ & $(0.0083)$ \\
\hline \multirow[t]{2}{*}{ Cost } & 0.7241 & $0.2120 * \star \star$ & $-0.6326 * \star \star$ & $-1.9436^{\star \star \star}$ & $-1.5217 * \star \star$ \\
\hline & $(1.8512)$ & (0.0199) & $(0.0820)$ & $(0.2290)$ & $(0.1933)$ \\
\hline \multirow[t]{2}{*}{ Top1 } & $0.0166^{* *}$ & $-0.0001^{\star *}$ & -0.0004 & $-0.0015^{\star \star}$ & -0.0001 \\
\hline & $(0.0065)$ & $(0.0001)$ & $(0.0003)$ & $(0.0007)$ & $(0.0006)$ \\
\hline \multirow[t]{2}{*}{ Growth } & -0.0365 & $0.0086^{\star \star \star}$ & 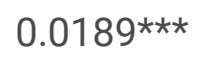 & 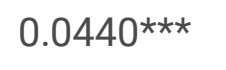 & $0.0244 * \star$ \\
\hline & $(0.0965)$ & $(0.0010)$ & $(0.0042)$ & $(0.0116)$ & $(0.0098)$ \\
\hline \multirow[t]{2}{*}{ GDP } & 1.1156 & $0.0799 * \star \star$ & 0.0491 & 0.1047 & 0.1919 \\
\hline & $(1.9729)$ & $(0.0212)$ & $(0.0816)$ & $(0.2280)$ & $(0.1924)$ \\
\hline \multirow[t]{2}{*}{ Market } & 0.0987 & 0.0008 & $-0.0096 * \star \star$ & $-0.0197 \star \star$ & $-0.0118 *$ \\
\hline & $(0.0696)$ & $(0.0007)$ & $(0.0029)$ & $(0.0080)$ & $(0.0067)$ \\
\hline Firm FE & Yes & Yes & Yes & Yes & Yes \\
\hline Year FE & Yes & Yes & Yes & Yes & Yes \\
\hline \multirow[t]{2}{*}{ Constant } & -0.2260 & $0.2406^{\star \star \star}$ & 0.1291 & 0.1645 & -0.3774 \\
\hline & $(2.3450)$ & $(0.0252)$ & $(0.1023)$ & $(0.2859)$ & $(0.2414)$ \\
\hline$N$ & 901 & 901 & 901 & 901 & 901 \\
\hline Adj $R^{2}$ & 0.1129 & 0.3512 & 0.3180 & 0.2595 & 0.2306 \\
\hline
\end{tabular}

Note: (1) ${ }^{\star \star \star} p<0.01,{ }^{\star \star} p<0.05, * p<0.1$. (2) Figures in parentheses are robust standard errors cluster on firm level. 
[1] STATA command "xtivreg2" detected the singleton groups, so there are 52 observations are not included in the IV-2SLS regression.

\section{Conclusion And Policy Implication}

Based on the data of Chinese A-share listed companies from 2008 to 2017, this paper manually collects the environmental R\&D data disclosed in corporate social responsibility (CSR) reports, and forecasts and analyses the impact of environmental tax on firm performance and its transmission path according to the practice of pollution charge in China. According to a series of empirical research results, we believe that the levy of environmental tax can promote firm performance and achieve the strong Porter effect, and this promotion effect is still effective in a long run. After introducing instrumental variables to deal with endogeneity and carrying out a series of robustness tests, we prove that the relationship between environmental tax and firm performance is a robust causality. However, it is worth noting that this paper only considers the firms that going concern, while the firms that are eliminated or shut down are not considered, so the conclusions in this paper may only be effective for the firms that are survived in the market. Our further study finds that environmental tax can improve firm performance by bringing effect of innovation compensation and firstmover advantage. Specifically, environmental tax promotes firms to increase environmental R\&D investment, bringing innovation compensation effect; environmental tax encourages firms to develop new environmentfriendly products and establish green corporate image, bringing first-mover advantage effect. And these two effects play a partial mediating role in the process of environmental tax affecting firm performance. The conclusions of this paper predict the implementation effect of Chinese environmental tax and provide micro evidence from China to verify the strong Porter hypothesis. This paper also focuses on the analysis of the two core paths of Porter hypothesis and interprets the ways to realize the "win-win" situation within environmental protection and firm competitiveness. Based on our findings, we provide the following policy implications:

First, governments should further strengthen the levy of environmental tax and improve the rigidity of law enforcement. For example, environmental administration department can further expand the scope of environmental tax and increase the levy rate on major pollutants to encourage firms to increase environmental R\&D and provoke strong Porter effect. The existing literature have pointed out an unfair phenomenon in the environmental management of Chinese local government, that is, state-owned firms and large tax payers are often given preferential treatment in environmental law enforcement (Xi et al., 2017; Huang and Lei, 2021). This unfair phenomenon will make firms that pay attention to environmental protection suffer from greater social costs and even furtherly lead to "bad money drives out good". Therefore, increasing the intensity of environmental tax appropriately and ensuring the fair implementation of environmental tax are the key points for Chinese environmental tax reform in the next step.

Second, firms should take green strategy proactively. When facing more and more strict environmental regulation, firms should realize that complying environmental regulation passively will only increase operating costs and is not conducive to the sustainable development. According to our conclusions, forward-looking corporate green strategies can benefit firms in two ways. On the one hand, firms that carry out environmental innovation actively can reduce pollution emissions and improve resource utility and productivity so as to take advantage of innovation compensation effect. On the other hand, firms will fully consider the green consumption preference of consumers in the market under such strategies and provide eco-friendly products 
to break the original market boundaries and establish the corporate social image of fulfilling social responsibilities actively, stimulating first-mover advantage effect to increase market share and enhance the long-term competitive advantage.

\section{Declarations}

Author contribution Zhuojun Lei: Conceptualization, Methodology, Software, Formal analysis, Data Curation, Writing (Original Draft). Lingyun Huang: Writing (Review and Editing), Supervision, Project administration, Funding acquisition Yao Cai: Data Curation, Writing - Review \& Editing, Visualization, Supervision

Funding We are grateful for the financial support from Western Project of National Social Foundation of China (19XJL006) and Chongqing Graduate Research and Innovation Project (CYS20052) and (CYB20054).

Data availability All data included in this study are available upon request by contact with the corresponding author.

Ethical approval and consent to participate Not applicable

Consent for publication Not applicable

Competing interests The authors declare that they have no conflict of interest.

\section{References}

1. Acemoglu D, Aghion P, Bursztyn L, Hemous D (2012) The environment and directed technical change. Am Econ Rev 102(1):131-166

2. Ambec S, Cohen MA, Elgie S, Lanoie P (2013) The Porter hypothesis at 20: can environmental regulation enhance innovation and competitiveness? Rev Env Econ Policy 7(1):2-22

3. Baron RM, Kenny DA (1986) The moderator-mediator variable distinction in social psychological research: Conceptual, strategic, and statistical considerations. J Pers Soc Psychol 51(6):1173

4. Berman E, Bui LT (2001) Environmental regulation and productivity: evidence from oil refineries. Rev Econ Stat 83(3):498-510

5. Brandt L, Van Biesebroeck J, Zhang Y (2012) Creative accounting or creative destruction? Firm-level productivity growth in Chinese manufacturing. J Dev Econ 97(2):339-351

6. Brouhle K, Graham B, Harrington DR (2013) Innovation under the Climate Wise program. Resour Energy Econ 35(2):91-112

7. Cagatay S, Mihci H (2006) Degree of environmental stringency and the impact on trade patterns. J Econ studies

8. Calel R, Dechezleprêtre A (2016) Environmental policy and directed technological change: evidence from the European carbon market. Rev Econ Stat 98(1):173-191

9. Copeland BR, Taylor MS (2004) Trade, growth, and the environment. J Econ Lit 42(1):7-71

10. Denison EF (2010) Accounting for slower economic growth: the United States in the 1970's. Brookings Institution Press 
11. Guo J, Fang Y, Yang Y (2019) Does China's Pollution Levy Standards Reform Promote Emissions Reduction? J World Econ 42:121-144

12. Hamamoto M (2006) Environmental regulation and the productivity of Japanese manufacturing industries. Resour Energy Econ 28(4):299-312

13. Hering L, Poncet S (2014) Environmental policy and exports: Evidence from Chinese cities. J Environ Econ Manag 68(2):296-318

14. Huang L, Lei Z (2021) How environmental regulation affect corporate green investment: Evidence from China. J Clean Prod 279:123560

15. Jaffe AB, Newell RG, Stavins RN (2002) Environmental policy and technological change. Environ Resour Econ 22(1):41-70

16. Jaffe AB, Palmer K (1997) Environmental regulation and innovation: a panel data study. Rev Econ Stat 79(4):610-619

17. Jian H, Yao L (2018) Pollution Spillover Effect and Environmental Tax Levy. Public Finance Research (04):75-85

18. Kammerer D (2009) The effects of customer benefit and regulation on environmental product innovation.: Empirical evidence from appliance manufacturers in Germany. Ecol Econ 68(8-9):2285-2295

19. López-Gamero MD, Molina-Azorín JF, Claver-Cortés E (2010) The potential of environmental regulation to change managerial perception, environmental management, competitiveness and financial performance. J Clean Prod 18(10-11):963-974

20. Lu H, Liu Q, Xu X, Yang N (2019) Can environmental protection tax achieve 'reducing pollution'and 'economic growth'? Based on the change perspective of China's sewage charges. China Popul Resour Environ 29:130-137

21. Manderson E, Kneller R (2012) Environmental regulations, outward FDI and heterogeneous firms: are countries used as pollution havens? Environ Resour Econ 51(3):317-352

22. Montero J (2002) Permits, standards, and technology innovation. J Environ Econ Manag 44(1):23-44

23. Morgan NA, Clark BH, Gooner R (2002) Marketing productivity, marketing audits, and systems for marketing performance assessment: Integrating multiple perspectives. J Bus Res 55(5):363-375

24. Nesta L, Vona F, Nicolli F (2014) Environmental policies, competition and innovation in renewable energy. J Environ Econ Manag 67(3):396-411

25. Peuckert J (2014) What shapes the impact of environmental regulation on competitiveness? Evidence from Executive Opinion Surveys. Environ Innov Soc Tr 10:77-94

26. Porter ME, Van der Linde C (1995) Toward a new conception of the environment-competitiveness relationship. J Econ Perspect 9(4):97-118

27. Rammer C, Gottschalk S, Peneder M, Wörter M, Stucki T, Arvanitis S (2017) Does energy policy hurt international competitiveness of firms? A comparative study for Germany, Switzerland and Austria. Energ Policy 109:154-180

28. Requate T, Unold W (2003) Environmental policy incentives to adopt advanced abatement technology: Will the true ranking please stand up? Eur Econ Rev 47(1):125-146 
29. Rubashkina Y, Galeotti M, Verdolini E (2015) Environmental regulation and competitiveness: Empirical evidence on the Porter Hypothesis from European manufacturing sectors. Energ Policy 83:288-300

30. Shang LN, Tan DQ, Feng SL, Zhou WT (2021) Environmental regulation, import trade, and green technology innovation. Environ Sci Pollut Res 1-11

31. Shen C, Jia NS, Li ZY (2017) Environmental regulation and industrial green total factor productivityempirical analysis based on command-control and market incentive regulatory tools. R\&D Manage 1(2):144-154

32. Song Y, Yang TT, Zhang M (2019) Research on the impact of environmental regulation on enterprise technology innovation-an empirical analysis based on Chinese provincial panel data. Environ Sci Pollut Res 26(21):21835-21848

33. Sun ZY, Wang XP, Liang C, Cao F, Wang L (2021) The impact of heterogeneous environmental regulation on innovation of high-tech enterprises in China: mediating and interaction effect. Environ Sci Pollut Res 28(7):8323-8336

34. Tombe T, Winter J (2015) Environmental policy and misallocation: The productivity effect of intensity standards. J Environ Econ Manag 72:137-163

35. Wang H, Yin JY, Li Z (2019) Will Introduction of Environmental Tax Affect Corporate TFP? Empirical Test Based on the Intensity of Collection of Pollutant Discharge Fees. Finance Trade Research 30(06):87-98

36. Wang Y, Li YX, Ma Z, Song J (2017) Media coverage, environmental regulation and corporate environment behavior. Nankai Bus Rev 12:42-54

37. Wang Y, Sun X, Guo X (2019) Environmental regulation and green productivity growth: Empirical evidence on the Porter Hypothesis from OECD industrial sectors. Energ Policy 132:611-619

38. Xi PH (2017) Fiscal Incentives, Environmental Preference and the Horizontal Environmental Management --From the Perspective of bargaining Power of Major Taxpayers. China Ind Econ 11:100-117

39. Xu BC, Xie JG (2016) How Pollution Charges Affect the Enterprise Productivity? Evidence from the Chinese Manufacturing Industry. J World Econ 39(08):143-168

40. Xu LP, Xin Y, Chen GM (2006) Ownership concentration, outside blockholders, and operating performance: Evidence from China's listed companies. Econ Res J 1:90-100

41. Xu W (2015) A Comparative Study of Environmental Protection Tax System and Pollutant Charge System. International Taxation in China (11):49-54

42. Zhang KK, Xu DY, Li SR, Wu T, Cheng JH (2021) Strategic interactions in environmental regulation enforcement: evidence from Chinese cities. Environ Sci Pollut Res 28(2):1992-2006

\section{Figures}



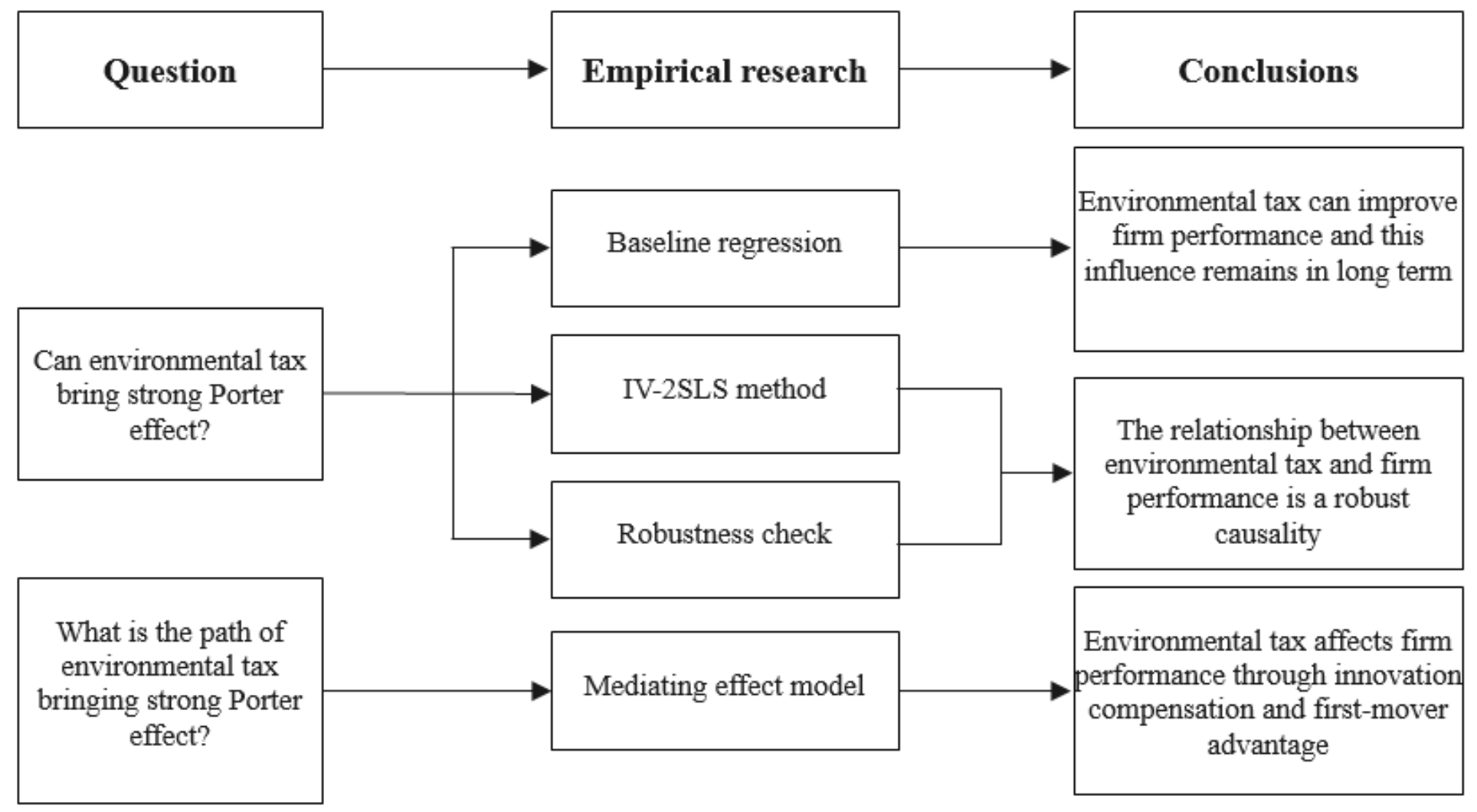

\section{Figure 1}

Empirical research framework 


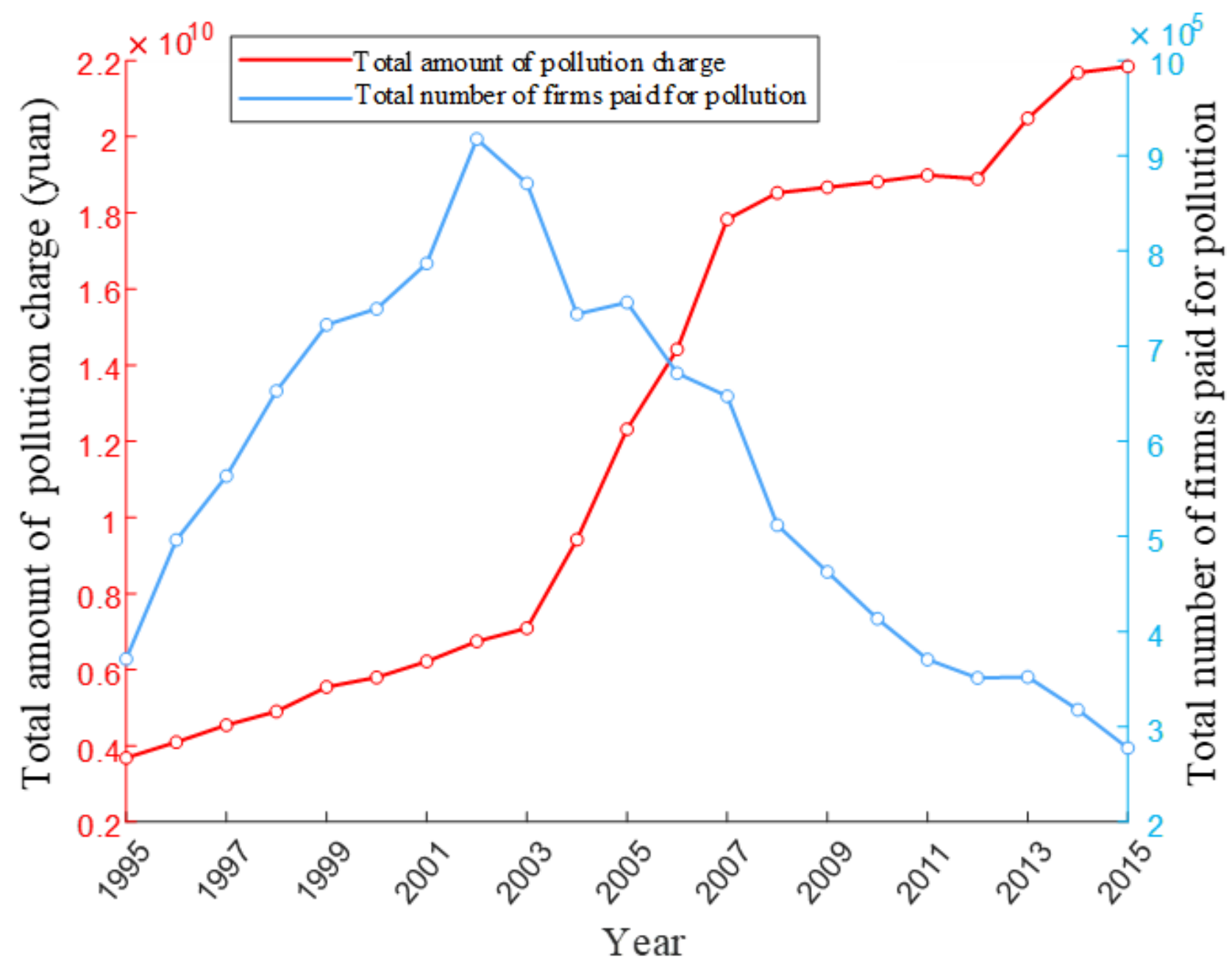

Figure 2

Total amount of pollution charge and total number of firms paid for pollution in China 


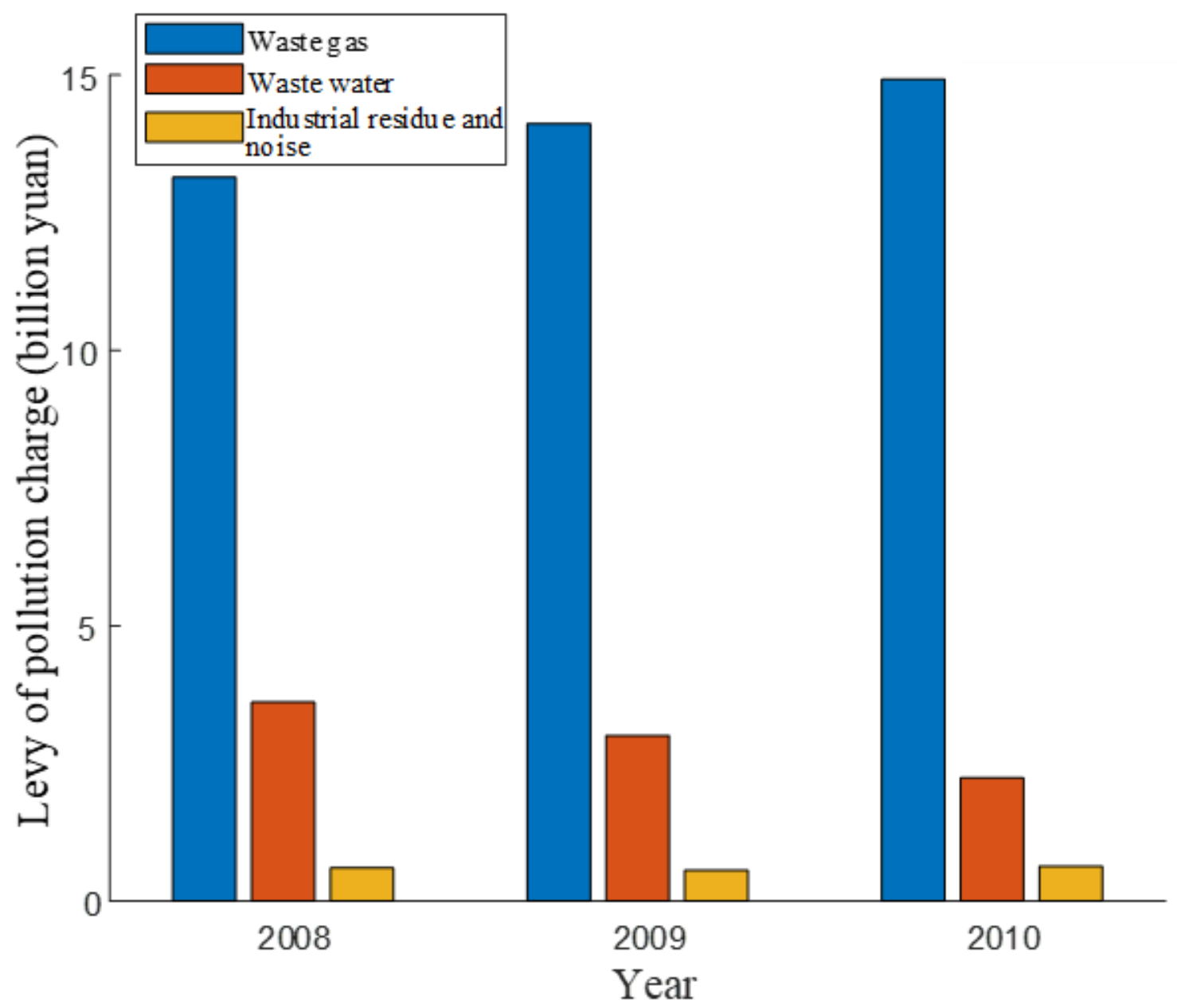

Figure 3

Details of pollution charge in China.[1]

[1] China Environmental Yearbook only disclosed the details of the pollution charge in these three years, but we can infer that the levy on waste gas and waste water also account for the most of the pollution charge in other years. 


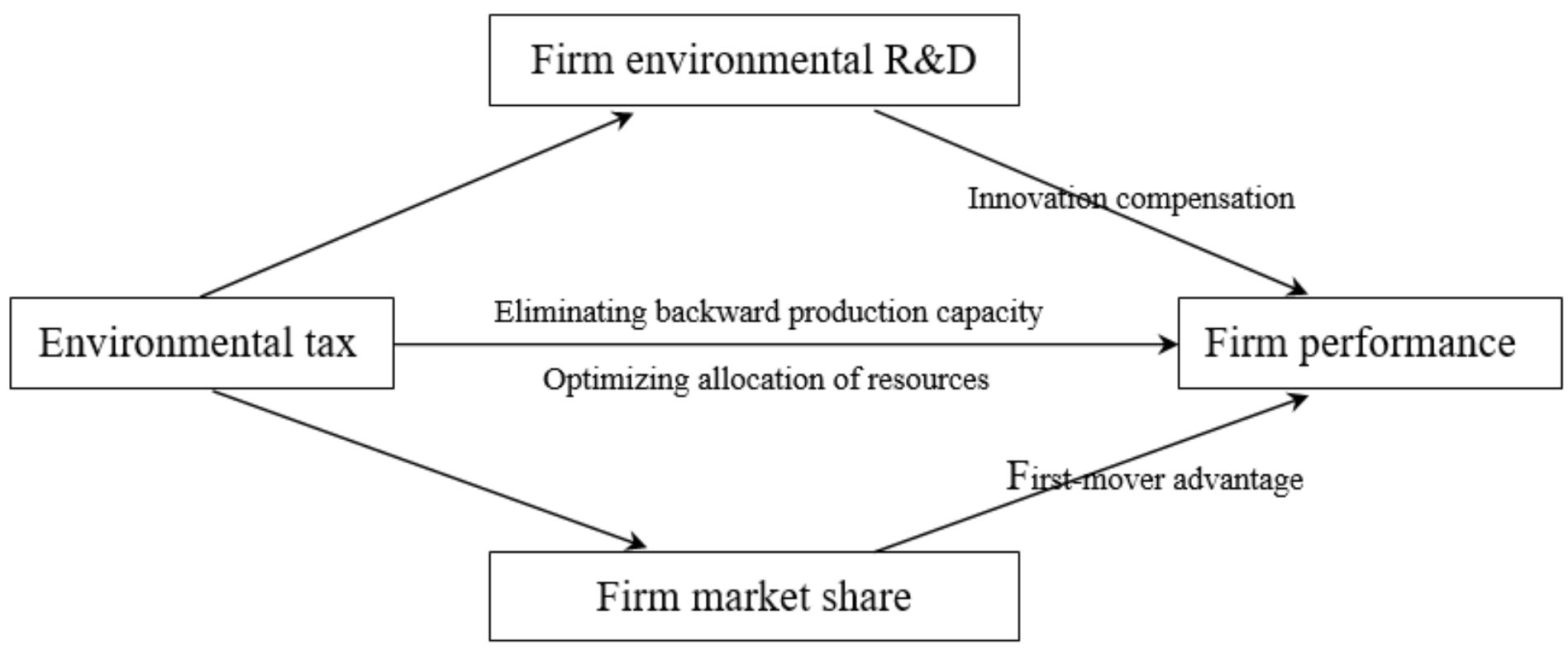

Figure 4

Paths of mediating effect. 